\title{
Milli mentalitet və stereotiplər kontekstində fərdi məlumatlara həssaslığın folklorik təzahürləri
}

\author{
Hikmot Quliyev \\ AMEA Folklor İnstitutu, Bak1, Azərbaycan \\ quliyevh@mail.ru
}

\begin{abstract}
Xülasə - Fərdi məlumatların təhlükəsizliyi müasir dövrün ən aktual problemlərindədir. İnternetin əsas kommunikasiya vasitəsinə çevrildiyi hazırki şəraitdə fərdi məlumatların təhlükəsizliyinin təmin edilməsi təkcə texnoloji deyil, eyni zamanda beynolxalq hüquq və milli mentalitetlə bağlı olan məsələdir. Məqalədə fərdi məlumat anlayıșı folklor kontekstində öyrənilmiş, milli mentalitet və stereotiplərin təsiri ilə meydana gələn və yaşadılan folklorik təzahürlər təhlil edilmişdir. Tədqiqata ənənəvi folklor nümunələri ilə bərabər, virtual sosial şəbəkələrdən qeydə alınmış faktlar da cəlb edilmişdir. Araşdırma nəticəsində müəyyən edilmişdir ki, Azərbaycan sosio-mədəni mühitində milli mentalitet vo stereotiplərdən qaynaqlanan fərdi məlumatlara həssaslıq sosial nəzarət və təzyiqin azaldığı virtual mühitdə daha çox ironiya predmetinə çevrilmişdir. Bu da virtual mühitdə özünməxsus folklor təzahürlərinin meydana çıxmasına səbəb olmuşdur.
\end{abstract}

Açar sözlori- milli mentalitet, stereotiplor, fordi molumatlar, informasiya tahlükssizliyi, internet folkloru, onənəvi folklor

\section{GİRIS}

Problemin aktuallığı. Fərdi məlumatların təhlükəsizliyi məsələsi müasir dövrün, xüsusilə də qloballaşma və virtuallaşma proseslərinin getdiyi, informasiya-kommunikasiya texnologiyalarının sürətlə genişləndiyi çağın ən aktual problemlərindəndir. Rəqəmsal kommunikasiya texnologiyalarında sürətlə qeydə alınan fərdi məlumatlar dövlətlərarası münasibətlərdən tutmuş, cəmiyyətin ən kiçik fərdlərinə qədər sosial gərginlik və konfliktlərin predmeti ola bilmək potensialındadır. Beynəlxalq hüquq və milli mentalitet, adət-ənənə və mənəvi dəyərlər, dini qayda və qanunlarla şərtlənən fərdi məlumatlar cari və strateji maraqlar, ictimai status və nüfuz və $\mathrm{s}$. baxımından mühüm əhəmiyyət kəsb edir. Odur ki, qlobal informasiya təhlükəsizliyi kontekstində fərdi məlumatların qorunması məsələsi bir tərəfdən texnoloji, digər tərəfdən sosial-mədəni, bütövlükdə isə, sosiotexnoji və kulturoloji problemdir və özünə münasibətdə multidissiplinar yanaşma tələb edir.

Məsələnin qoyuluşu. Folklor milli mədəniyyətin tərkib hissəsi kimi özündə milli mentalitet və stereotipləri yaşatmaqdadır. Daha dəqiq ifadə etsək, milli mentalitet və stereotiplər cəmiyyətdə qarşılıqlı münasibətlər zəminində ortaya çıxan, təkrar-təkrar istifadə olunmaqla sabitləşən, "basmaqəlib" düşüncə və önyarğılar sistemidir ki, onun izlərini ən müxtəlif formalarda, eləcə də folklorda müşahidə edə bilərik. Azərbaycan sosio-mədəni mühiti özünün etno-genetik tipologiyası və tarixi inkişaf dinamikası baxımından bir tərəfdən ümumtürk mədəni ənənələri, digər tərəfdən isə ümumşərq və müsəlman dəyərləri ilə sıx bağlıdır. Bununla əlqədar olaraq, Azərbaycan milli metaliteti və stereotipləri özündə həm ümumtürk, həm də ümummüsəlman dəyər və yanaşmalarını yaşatmaqdadır. Lakin "folklorun simvolik dilini və metaforik təbiətini formalaşdıran psixoloji və sosioloji şərtlər" (6: 73) zaman-zaman dəyişdiyi üçün folklorda meydana çıxan stereotiplərin də məzmunu, mahiyyəti və hədəfi dəyişir. Təsadüfi deyildir ki, ənənəvi folklorun yarandığı, söyləndiyi və variantlaşdığ 1 mühitin psixososial şərtləri ilə virtual folklorunku biri-birindən fərqlənir. Bu fərqləri fərdi məlumatlara həssaslıqla bağlı olan stereotiplərin folkorik təzahürlərində də müşahidə etmək mümkündür.

\section{II. ӘNӘNӘVİ FOLKLORDA FӘRDİ MӘLUMATLAR: MILLII MENTALİTET Və STEREOTİPLOR}

Metodoloji olaraq bir məsələni vurğulamaq vacibdir ki, folklorda fərdi məlumat anlayışı fərdin özü barədə təsəvvürləri kimi deyil, kollektivin fərd haqqında ümumiləşmiş baxışları stereotipik münasibəti olaraq dərk olunur. Biz də tədqiqat zamanı fərdi məlumatların təhlükəsizliyi məsələsinə, fərddən fərdə baxış kontekstində deyil, folklorun təbiətinə müvafiq olaraq, kollektivin fərdə münasibəti əsasında yanaşmışıq. Çünki folklorla ifadə olunan stereotiplər, əslində, gerçəkliyin özündən daha çox, onun haqqinda olan fantaziyalardan ibarətdir. Bir qrupun başqa bir qrup və müəyyən bir fərd haqqında sabitləşmiş düşüncə və fikri, hazırqəlib (basmaqəlib) baxış və adlandırmaları şəklində özünü göstərən stereotiplər (4; 3 ; 8) sosial mühitdə davranış və münasibətlərin nizamlanmasında mühüm təsirə malikdir. İstər üz-üzə, istərsə də virtual kommunikativ mühitdə fərdlərarası və qruplararası münasibətlərin qurulmasında, daha sürətli inteqrasiya prosesinin getməsində, eləcə də qarşıdurma və toqquşmaların meydana çıxmasında stereotiplərin rolu vardır. Kişilərin qadınlar, qadınların kişilər, müəyyən peşə sahiblərinin digər peşə sahibləri barədə steretipik təsəvvürləri, əslində, obyektin özünün yox, o təsəvvürü istehsal edən subyektin münasibətinin ifadəsidir.

Ogər biz ənənəvi xalq mədəniyyətində fərdi məlumat anlaşıyına nəzər yetirsək görərik ki, burada məlumat anlayışı daha çox "söz" kimi dərk olunur. Söz haqqında olan linqvopetik təsəvvürlər isə, onu hərəkətdə, dinamikada olan 


\section{“Informasiya tohlükosizliyinin aktual multidissiplinar elmi-praktiki problemlori” V respublika konfransı, 29 noyabr 2019-cu il}

varlıq kimi qavrayır. Faktlara diqqət yetirək: "Söz tez yayılar" (16: 366), "Sözün ayağı yoxdur, amma gazir hor yanı" (12: 367), "Sözün qanadl var" (12: 367), "Sözün qadəmi yeyin olar" (12: 367), "Sözün damarl olar, çəkdikcə uzanar" (12: 367), "Söz quşdu, buraxarsan, uçar gedər” (12: 366), "Sözdən söz çıxar, ocaqdan köz” (12: 367).

Sözün hərəkətdə olan varlıq kimi dərk olunması, fərdi məlumatların, şəxsə, ailəyə, tayfaya, müəyyən peşə və ya sənətə dair biliyin yayılması təhlükəsinə olan həssaslığı ifadə edir. Mədəniyyət özü-özünü təşkil edən sistem kimi bir tərəfdən fərdi məlumatın, müəyyən biliyin, sirrin yayılması təhlükəsini "hiss edərək" onu qorumağı təlqin edir, digər tərədən isə, gizili bilik və məlumatı əldə etməyi, ona olan marağı da özündə ehtiva edir. Çünki folklorda eyni zamanda informasiyanın konfidensionallığını aradan qaldıran, tabu və normaları pozan yanaşma və baxışlar da vardır. Çünki mədəniyyət həm vetolaşdıran, həm də sanksiyalaşdıran sistem kimi özünü göstərir. Gizli informasiya və ya bilik qarı, dərviş, xtonik varlıqlar, liminal obrazlar tərəfindən, eləcə də müəyyən psixofizioloji hallar - dəlilik, axmaqlıq, sərxoşluq və $\mathrm{s}$. vasitəsilə əldə olunur və ya yayılır. Mədəniyyət hər iki mövqe üçün çıxış yolu təqdim edir. Dədə Qorqud, Molla Nəsrəddin müdrik, ağsaqqal, trikster-axmaq kimi həm norma yaradan, həm də normanı pozan obrazlar kimi özünü göstərir.

$\mathrm{Bu}$ baxımdan yanaşdıqda ənənəvi xalq mədəniyyətində fərdi məlumatlara həssaslıqdan doğan, həm onu qorumaq, həm də yaymaqla bağlı kollektiv rəyləri fərqləndirə bilərik:

\section{Әnənədə fərdi məlumatların təhlükəsizliyinə} həssaslıqdan doğan deyimlər: "Bir daş altda bir daş üstdə”, "Yerin do qulağl var", "Söz ki ă̆lzdan çıxdl sanin deyil”, "Söz var el içindo, söz var ev içində” (12: 366), "Ev bizim, sirr bizim" (12: 126).

Fərdi məlumatın təhlükəsilziyinə olan həssaslıq folklorda sirr anlayışının meydana çıxmasına səbəb olmuşdur. Bu sözün Azərbaycan dilinin izahlı lüğətindəki mənası belədir: 1) Başqalarından gizli saxlanılan, başqalarına bildirilməyən, deyilməyən, hamının bilməli olmadığı söz, iş və s; 2) Hələ açılmamış, dərk edilməmiş, öyrənilməmiş bir müəmma kimi qalmış şey (9: 127). Folklordakı sirr anlayışı məhz birinci mənada istifadə olunur. Təbii ki, sirr kimi qriflənən informasiya özündə cari və ya strateji məna ifadə edən biliyi ehtiva edir. $\mathrm{Bu}$ da, sosial münasibətlərdə, davranış və inanclarda müəyyən sərhədd və distansiyanın yaradılmasına xidmət edir. Sirr anlayışı ilə bağlı dilimizdəki faktlara nəzər yetirsək, burada cari və strateji maraqlara xidmət edən, inanc və sakral dəyərlərlə qorunan, bütövlükdə isə, mentalitetlə bağl1 olan məqamlara rast gələ bilərik. V.Haqverdiyev sirlə bağlı faktları və onların kəsb etdiyi mənaları aşağıdakı kimi qeyd edir: "Sirrivi vermo yaruva, yaruvun da yarl var", "Hor gördüyünü dost sanıb sirrini açma", "Düşmənə sirr, dosta yalan söylamə", "Ev bizim, sirr bizim", "No dil bilsin, no dodaq" kalamlart sirr saxlamaq üçün onu heç kima etibar etməməyi məsləhət görür, çünki "Sirr, ikinin arasinda qalar, üçə geçdi, qapını açar". Digər ifadələr isə: "Özgənin sözünü özgənin evinda danışma", "Sirr açandan el qaçar", "Özgənin sözünü özgəyə deməyə nə var?" göstarir ki, bildiyin sirri açmaq on asan iş olsa da o, adamı gözdon salır, belo adamlara hər yerdə hörmət edilmir" (2: 10). Göründüyü kimi, ənənəvi xalq mədəniyyətində sirri saxlamaq, onu qorumaq ciddi şəkildə təbliğ olunmaqla bərabər, sirri açmaq da neqativ davranış kimi qiymətləndirilir. Yeri gəlmişkən onu deyək ki, qrup idiokulturasının formalaşmasında, qrupa məxsus informasiya və davranışlarının möhkəmlənməsində sirr saxlama mühüm rola malikdir.

Onənədə fərdi məlumatları qorumaqla bağlı stereotip adlandırmalar vo təbliğatlar: "Sinəsi qabirstanlıq", “ă̆zıbütöv”, “ăgzıbərk”, “kişi gördüyün deməz”, “kişinin hülqumu olar”, "kişinin yanında baş kasərlar” və s.

Onənədə fərdi məlumatı yaymaqla bağlı stereotip adlandırmalar: "ă̆zıboş”, “arvadağız”, "hülqumsuz”, "küpagiron qarl”, "söz gazdiran”, "simsiz teleqraf”, "qeybat edan arvad”, casus va s.

Bundan əlavə ənənədə fərdi məlumatı yaymağın forması ilə bağlı kommunikativ aktlar mövcuddur: "pıça-pıç”, “dediqodu”, "qeybat" vas.

Göründüyü kimi, Azərbaycan sosio-mədəni mühitində fərdi məlumatlar folklorda, ənənəvi xalq mədəniyyəti və etnoqrafik yaddaşda stereotiplərlə hərəkətə gətirilən və yaşadılan, qruplararası münasibətlərin qurulması və tənzimlənməsində mühüm rol oynayan faktorlardan biri kimi çıxış edir.

Hazır nümunə, sabitləşmiş baxış, öncədən müəyyənləşmiş rəy kimi özünü göstərən stereotiplər adət-ənənə, dini ehkam və qadağalarla çulğalaşaraq ictimai münasibətlərdə dərin sosial gərginliklərin və konfliklərin yaranmasına da təkan verir.

"Kitabi-Dədə Qorqud" eposunun "Bəkil oğlu İmran" boyunda ov vaxtı atdan yıxılan Bəkilin ayağı sındığı üçün beş gün divana çıxmır. Lakin bir gün xatunu ondan bunun səbəbini soruşduqda Bəkil sirrini deyir. Arvad1 "olin əlinə çald, qaravaşa söylədi. Qaravaş çıqub qapuçıya söylədi. Otuz iki dişdən çıqan bütün orduya yayıldı, "Bəkil atdan düşmüş, ayağ sınmış" deyü” (5: 138). Kişilik idiokulturası əsasında yaradılan və qadının daha çox neqativ plana yerləşdirildiyi "Kitabi-Dədə Qorqud" eposunda Bəkilin sağlamlığı ilə bağlı strateji informasiya məhz onun xatunu tərəfindən yayılır. Eposda "Otuz iki dişdən çıxan" fərdi məlumat qadının neqativ planda təqdim edilməsi fonunda mənfi davranış kimi əsaslandırılır.

Milli mentalitet və stereotiplərin təzyiqi kontekstində klassik adəbiyyata müraciət etsək, görərik ki, Qeysi Məcnun edən öz dövrünün adət-ənənələrinə, mental və dini qaydalarına riayət etməmək olmuşdur. Məcnunluq, əslində Şərq-müsəlman mühitində sərt dini qayda-qanunların təzyiqi altında yığılan potensial enerjinin mədəni yaradıcılıq platformasında özünə tapdığ́ çıxış yolunun təzahürüdür. Kənardan cünunluq kimi görünən davranışın batinində sosial norma və prinsiplərə, stereotiplər və mentalitetdən enerji alan ehkamlara kəskin protest mövcuddur. Q.Quliyev yazır ki, “...Füzulinin Qeysinin son nəticə etibarı ilə dəli-divanəyə çevrilməsinin, biyabanlara düşməsinin dəruni səbəbi antihumanist adət-ənənələrdə, qaydaqanunlardadir" (7:146). 


\section{"Informasiya tohlükəsizliyinin aktual multidissiplinar elmi-praktiki problemlori” \\ V respublika konfransı, 29 noyabr 2019-cu il}

Həmçinin Azərbaycan kino sənətinin ən dəyərli incilərindən olan "Arşın mal alan" filmində qaldırılan problem məhz gənc tacir Osgər bəyin evlənmək fikrinə düşməsi zəminində q1zı toydan öncə görmək, sevmək istəyidir ki, dövrün qaydaları, yəni milli mentalitet və stereotiplər buna imkan vermir. Dostu Süleyman bəy ona "arşın malçı" cildinə girməyi tövsiyə edir. Yadımıza folklorda "təğyiri-libas olma" ilə bağlı faktları salaq. Tacir Osgər də "təğyiri-libas" olmaqla, yəni "arşın malçı" cildinə girməklə fərdi məlumatlara giriş üçün "viza" alır. Nağıllarda məhz qarı obrazları özünün yaşl1lığ1 və ağbirçəkliyindən istifadə edərək qalada olan şahzadəni görməyə və aldatmağa nail olur. Mədəniyyətdə ağsaqqallıq və ağbirçəkliyin kəsb etdiyi məna ona fərdi məlumatlara çıxış imkanı yarada bilmişdir.

Beləliklə, ənənəvi folklor mühiti və münasibətləri kontekstində fordi məlumatlara olan həssaslığın əsasında milli mentalitet və stereotiplərdən qaynaqlanan sosial nəzarət və təzyiq dayanır. İstər folklor nümunələrində, istər etnoqrafik yaddaş faktlarında, istərsə də yazılı ədəbi əsərlərdə ictimai nəzarət və təzyiqin hərəkətverici mənbəyi olan stereotiplər eyni zamanda fərdi məlumatların - şəxsə, ailəyə, qrupa və s.-yə aid informasiyaların da qorunması və təhlükəsizliyinin təmin edilməsi baxımından mühüm rola malikdir.

\section{INFORMASIYA COMIYYӘTİ KONTEKSTINDӘ FORDİ MӘLUMATLARA MÜNASIBBT: FOLKLORIK REAKSIYA}

Qeyd etdiyimiz kimi, Azərbaycan sosio-mədəni mühiti özünün genezisi etibarı ilə bir tərəfdən türk etnik-mədəni dəyərlərinə, digər tərəfdən isə islam dini prinsiplərinə əsaslanır. Şübhəsiz ki, burada ənənə və yaddaş hesabına möhkəmlənən, sosial stereotip və psixoloji gerçəkliklə korelyasiya olunan davranışlar mövcuddur. Sosial stereotiplərin və milli mentalitetin təzyiqi altında daim aktual qalan müəyyən davranışlar vardır ki, bunların kökü psixoloji kompleks və narahatlıqlardan qaynaqlanır. Məsələn, oğulun atanın yanında övladını qucağına alması və ya atanın qarşısında uzanaraq yatması Azərbaycan mühitində tərbiyəsizlik, böyüyə hörmətsizlik kimi dəyərləndirilir. Həmçinin süfrə ətrafinda yaşl1ların, valideynlərin olduğu şəraitdə gənclərin uca səslə danışması cəmiyyətimizdə qeyri-etik davranışlar kimi qiymətləndirilir. Yaxud Azərbaycan mühitində ev tikən şəxs evin pəncərələrini elə yerləşdirməlidir ki, qonşunun həyətini görməsin. Həmçinin ev tikilərkən ən mühüm şərtlərdən biri onun üzünün Qibləyə tərəf olmasıdır ${ }^{1}$. Bu, bir yandan dini

\footnotetext{
1 “Azərbaycanda şəhər tipli yaşayış məskənlərinin əsas xarakterik xüsusiyyətlərindən biri onlarda evlərin fasadının həyətə tərəf istiqamətləndirilməsidir. Ailə məişətinin spesifikası ilə bağlı olan belə planlaşdırma keçmişdə bütün müsəlman Şərqində mövcud idi. Lakin sonralar bu cəhətlər aradan qaldırılmış, şəhər tipli yaşayış məskənlərinin inkişafında yeni memamrlıq elementləri (küçəyə açılan pəncərə və eyvanlar, milli ornamentlərlə bəzədilmiş və taqqulbablar qoyulmuş geniş darvaza və alaqapılar və s.) meydana gəlmişdir" (11: 26). Həmçinin elə həmin oçerkdə qeyd olunur ki, "Evlərin küçəyə baxan arxa divarlarında pəncərə açırımlarının qoyulmaması son dövrlərə qədər Şərq ölkələrində mövcud olmuş $\boldsymbol{e v}$ moişətinin vo ailonin həyat torzinin yad nozərlordon mühafizo edilmosi (kursiv bizimdir - H.Q.), habelə küçənin tozlu havasının evin otaqlarına dolmasının qarşısının alınması mülahizəsi ilə izah olunur” (11: 33).
}

məzmun kəsb edirsə, digər tərəfdən də ekoloji əhəmiyyətə malikdir. Yaxud kənd yerlərində evlərin hasarlanması ${ }^{2}$, bəzən həmin hasarların hündürlüyünün həddindən artıq çox yüksək olması da fərdi məlumatlar silsiləsinə daxil olan ailə həyatının (daha çox həyat yoldaşı və qızların) gizlədilməsi, qorunması anlamını ifadə edir. Göründüyü kimi, Azərbaycan etnoqrafik gerçəkliyində insanın yaşayışı üçün zəruri olan evin tikilmə qaydası, digər faktorlarla yanaşı folklorik davranışlarla - milli mentalitet və stereotiplərlə tənzimlənir. Etnoqrafik təsvirlərdən məlum olur ki, "Naxçıvan bölgəsində qapı (darvaza) üzərinə bərkidilmiş taqqılbabla evin kişisi, zəndulbabla evin xanımı çağırılardı" (15: 38). Naxçıvanın "El həyatı" qəzetinin 26 may 2019-cu il sayında bu məlumat aşağıdakı kimi əks olunmuşdur: "Qədimdən Ordubadda həyət qapılarının üzərinə iki balaca dəzgah vurulardı. Onlardan ev sahibini qapıya çağırmaq üçün istifadə edilərdi. Dəmirdən düzəldilən bu dəzgahlardan biri uzun olduğuna görə taqqulbab, o biri isə aypara və ya ürək şəklində olduğundan "Zəncirbab" adlanard1. "Taqq1lbab"1 döyəndə qapıya kişi çıxar, "Zəncirbab" səsinə isə qadınlar səs verərdi" (10). Göründüyü kimi, fərdi məlumatlara olan həssaslığın səviyyəsi müəyyən dövrlərdə səs informasiyasının kəsb etdiyi mənanın fərqləndirilməsi ilə də işarələnmişdir. Müsəlman dini adətlərinin izi kimi özünü göstərən bu faktın mahiyyətində qadın və kişi qrupunun fərqləndirilməsi özünü göstərir. Naməhrəmlik təhlükəsi kontekstində icra olunan bu davranış milli mentalitetdə fərdi, şəxsi həyatın çox ciddi şəkildə qorunduğunu sübut edir. Bu tipli məsələlər gündəlik məişət həyatı ilə bağlı olan etnoqrafik faktlarda geniş şəkildə öz əksini tapmışdır.

Milli mentalitet və stereotiplərlə tənzimlənən ənənəvi sosial mühitlər - kənd, qəsəbə, müəyyən dövrlərdə isə şəhər (məhəllələr qismində) həyatı üçün daha çox aktual olan yuxarıdakı adət və ənənələr kommunikasiya imkanlarının genişlənməsi, şəhrələşmə və sənayeləşmə prosesləri kontekstində öz təsir gücünü itirməkdədir. Çünki kommunikasiya imkanlarının məhdudluğu, təhsil, dünyagörüş və savadlılığın aşağı səviyyədə olduğu şəraitdə və toplumlarda sosial münasibətlərin əsas tənzimləyicisi adət və ənənələr, mentalitet və stereotiplər idi. Ağsaqqal və ağbirçəklərin, atalar sözü və məsəllərin, inanc və yasaqların hakim ideoloji konsept kimi çıxış etdiyi qapalı mühitlərdə, təbii ki, stereotiplərin basqısı daha kəskin olmuşdur. Kommunikasiya imkanlarının genişlənməsi, urbanizasiya və sənayeləşmə proseslərinin sürətlənməsi, elmi-texnoloji sferadakı yeniliklər sosiumları qapalılıqdan azad edir.

Şübhəsiz ki, sənayeləşmə və şəhərləşmə proseslərinin təsiri, informasiya-kommunikasiya texnologiyalarının meydana çıxması və s. kimi faktorlar sosiumun həyat tərzinə, dünya görüşünə, qarşılıqlı münasibətlərinə, adət-ənənələrinə öz təsirini göstərir. Lakin unutmaq olmaz ki, yaşayış məskənindən, sosial-mədəni proseslərin xarakterindən, ictimai quruluşun spesifikasından, əmək və istehsalat proseslərinin

\footnotetext{
2 "Kəndli həyətlərini xarici mühitdən təcrid etmək, Şərq adətincə onun qapalılığını təmin etmək və ümumi kompozisiyanı tamamlamaq üçün Azərbaycanın bütün bölgələrində həyətlərin ətrafına hasar (barı, çəpər) çəkilirdi” (11: 34)
} 


\section{“Informasiya tohlükosizliyinin aktual multidissiplinar elmi-praktiki problemlori” \\ V respublika konfransı, 29 noyabr 2019-cu il}

səciyyəsindən, harada və necə yaşamasından asılı olmayaraq, kommunikativ mühitdə olan fərdlər və ya qruplar özləri və başqaları, eləcə də başqalarının onlar haqqında düşündükləri barədə fantaziyalara, əvvəlcədən hazır düşüncələrə, önyarğı və mühakimələrə, daha dəqiq desək, stereotiplərə sahibdirlər. Nəzərə alsaq ki, stereotiplər təkcə şüurlu şəkildə deyil, eyni zamanda kollektiv şürsuzluq faktı kimi də özünü göstərir, o halda virtual kommunikativ mühitə qədəm qoyan, orada özünə məskən salan, virtual dünyasını və ənənələrini formalaşdıran yeni insan nəslinin də özünəməxsus stereotipləri və dəyərləri mövcuddur deyə bilərik. Xüsusən də fərdi məlumatlara, şəxsi həyat və mənəvi məsələlərlə bağlı olan informasiyalara münasibətdə milli mentalitet və stereotiplərdən qaynaqlanan reaksiyaların spesifikası çox mühüm əhəmiyyət kəsb edir.

Milli mentalitet və stereotiplərin təzyiqi kontekstində fərdi məlumataların qorunması məsələsi İKT-nin meydana gəlməsi şəraitində tamamilə fərqli mədəni təzahürlər doğurmuşdur. Belə ki, bir tərəfdən milli mentalitet və stereotiplərin basq1s1, digər tərəfdən isə İnternetin təqdim etdiyi geniş imkanlar fərdi məlumatların təhlükəsizliyi üçün ziddiyyətli bir situasiyanın ortaya çıxmasına səbəb olmuşdur. Fərdi məlumatların təhlükəsizliyi ilə bağlı müəyyən normativ-hüquqi sənədlər mövcud olsa da, bu sahədə məsələ həm də milli mentalitetlə s1x bağlıdır. Akademik R.Oliquliyev fordi məlumatların milli mentalitetlə bağlılığı barədə yazır ki, "Fərdi məlumatlardan istifadə ilə bağlı hüquqi məhdudiyyətlərə baxmayaraq, onlardan qeyri-qanuni biznes və kriminal məqsədlərlə istifadəyə olan tələbat bu sahənin "qara bazarı"nın formalaşmasına rəvac verir. Beləliklə, fərdi məlumatlar həm də kriminalistikanın predmetinə çevrilir.

Fərdi məlumatların virtual mühitdə dövr etməsi bu kateqoriyadan olan məlumatların yalnız milli qanunvericilik çərçivəsində qorunmasının artıq qeyri-mümkün olmasına gətirib çıxardır. $\mathrm{Bu}$ da fərdi məlumatlarla bağlı ictimai münasibətlərin qlobal miqyasda, beynəlxalq hüquq çərçivəsində həllini tələb edir. Lakin beynəlxalq miqyasda tərəflər arasında konsensusun əldə edilməsi o qədər də asan məsələ deyil. Çünki "şəxsi həyat" normaları, adətənənələri, "fərdi məlumat" anlayışları müxtəlif milli mentalitetlərdə fərqli şəkildə anlaşılır. Müvafiq beynəlxalq hüquqi prinsip və standartlar isə milli adət-ənənələri, mental dəyərləri nəzərə almır.

Bu sahədəki problemlər həm də sosial-iqtisadi, psixoloji, kulturoloji və s. aspektli olduğu üçün məsələnin həlli multidistiplinar yanaşma tələb edir (1: 118). Göründüyü kimi, alim haqlı olaraq, fərdi məlumatların təhlükəsizliyi məsələsində beynəlxalq hüquq və normalarla tənzimlənməyən milli mentalitet məsələsini irəli sürür. Qeyd edir ki, hər bir milli mühitdə fərdi məlumatlara həssaslıq spesifik xarakter daşıyır. Azərbaycan sosio-mədəni mühiti mahiyyəti etibarı ilə konservativ xarakterə malik olduğu üçün burada fərdi məlumatlara həssaslıq səviyyəsi (milli mentalitet və stereotiplərin təzyiqi hesabına) daha kəskin şəkildə özünü göstərir. Belə ki, şəxsi, fordi hoyatdan tutmuş, ailo, övlad, qohum-oqraba, var-dövlot, mal-mülk, eloco do istirahot vo aylancəyə qədər olan hər bir məlumat milli mühitdə strateji məna kəsb edir. Müəyyən bir ehtiyatsızlıq və diqqətsizlik həmin məlumatların ictimailəşməsinə, son nəticədə sosial, siyasi, iqtisadi, hətta psixoloji problemlərin də ortaya ç1xmasına gətirə bilər. Belə bir şəraitdə Azərbaycan sosiomodoni mühitindo Internet tokco olçatan, asan kommunikasiya vasitosi deyil, daha çox sosial tozyiq vo ictimai qınağın "buxovundan" xilas olmaq üçün çıxış yoludur. Xüsusən də anonimlik, gizlilik, "fake profile" və "nickname”-lər hesabına şəxsiyyətin gizlədilməsi, başqa ad və ya ləqəblərdən istifadə etmənin mümkünlüyü, sosial şəbəkə hesablarının parol və kodlarla qorunması, yüksək təhlükəsizlik imkanlarının mövcudluğu İnterneti milli mentalitet və stereotiplərin təzyiqindən xilas olmaq üçün "oazis"-ə çevirmişdir. Oslində, şəxsiyyətini (özünü) gizlətmə və bundan doğan mədəni təzahürlərin arxasında sosial stereotiplər və milli mentalitetdən qaynaqlanan, eləcə də psixoloji kompleks vo narahatlıqlarla korelyasiya olunan gizli ehtiyaclar dayanır.

Lakin İKT-nin inkişafi, sosial şəbəkə və platformaların meydana gəlməsi geniş imkanlarla bərabər (komunikasiya əlçatandır, ünsiyyət və münasibət üçün ən müxtəlif platformalar mövcuddur, özünüifadə etmək, duyğu və hislərini, qayğı və narahatlıqlarını paylaşmaq üçün geniş imkanlar vardır), təhlükə və təhdidlərin (lakin bütün məlumatalar, hərəkət və davranışlar, status və kommentlər, yazışma və danışıqlar fasiləsiz olaraq qeydə alınır, məhrəm, pünhan məsələlərin üzə çıxarılması, ictimailəşdirilməsi üçün də potensial təhlükələr meydana gəlir, xüsusən də şantaj, şər, böhtan, yalan, hado-qorxu vo s. tipli narahatlıqlar yarada biləcək situasiyalar mövcuddur) də meydana çıxmasına səbəb olmuşdur.

Təbii ki, hazırki dövrdə hər bir mobil telefon, planşet, kompüterlər şəxsi əşya kimi müəyyən bir fərdə aiddir. Hər bir şəxs özünəməxsus olan gerçəkliyi, dünyanı həmin rəqəmsal vasitələrdə yaradır, inşa edir. Fərdi rəqəmsal vasitələrin foto və video qalereyadan tutmuş, Watsap, Instagram, Facebook və s. hesablarda olan şəxsi məlumatlara, yazışma və danışıqlara qədər hər bir detal müasir dövrdə istənilən şəxsin Profilini, CVsini, ənənəvi şəkildə desək, şəxsi işini bərpa etməyə imkan verir. Odur ki, rəqəmsal ünsiyyət vasitəri, sosial şəbəkə platformaları hər bir şəxsə məxsus parol və ya kodlarla qorunur.

Sosial media platformalarında, sosial şəbəkə və forumlarda fərdi məlumatların qorunması zərurəti konteksində meydana gələn çoxlu sayda folklorik faktlar və rəylər mövcuddur. Belə ki, telefon, planşet, kompüter vo s. kimi texnoloji avadanlıqlarda gündəlik yaşamdan formalaşan "data"-lar mövcuddur ki, onların bir qismi həssaslıq tələb edən "məhrəm", “fərdi", "personal”, "gizli" informasiyalardır. WhatsApp, Instagram, Messenger, Facebbok, Twitter vo s. sosial media platformalarında gündəlik kommunikasiya və təmasdan yeni tanışlıqlar, münasibət və sosiallaşmalar meydana çıxır. Elə sosial şəbəkələrin yaradılmasındakı ilkin məqsəd və təkan da gənclərin ünsiyyət qurması, yeni tanışlıqlar əldə etməsi, yeniyetmələrin özünüifadə və özünütəsdiqetmə imkanlarının yaradılması idi. Çünki şəhərləşmə və müasir infrastrukturdan irəli gələn məskunlaşma forması - yüksək mərtəbəli binalar, hər cür kollektivləşmə və sosiallaşmanın 


\section{“Informasiya tohlükosizliyinin aktual multidissiplinar elmi-praktiki problemlori” \\ V respublika konfransı, 29 noyabr 2019-cu il}

qarşısını alan həyat tərzi və s. fərdiliyə, tənhalığa səbəb olur ki, şəhər həyatının, böyük meqapolislərin ən mühüm problemlərindən biri də sosiallaşma və kollektivləşmə, iç-içə yaşam şərtlərindən məhrum olmasıdır. Belə bir şəraitdə virtual kommunikativ mühitlər, sosial şəbəkə və platformalar yeniyetmə və gənclərin əsas görüş yerinə çevrilir. Artıq ünsiyyət və təmas, tanışlıq və münasibət heç bir maneə və sərhədd olmadan, hətta psixoloji barierlərin aradan qalxmas1 şəraitində baş verir ki, bu da İnternet istifadəçiləri üçün əlahiddə imkanların yaranmasına, heç bir məkanda olmadıqları qədər sərbəstlik əldə etməsinə gətirib çıxarır. Anonimlik, ictimai nəzarətsizlik və normativ-hüquqi boşluğun sosial şəbəkə iştirakçıları və ya istifadəçiləri üçün yaratdığ mühit ifrat sərbəstliyə yola açır ki, bu da bəzən təhlükə cə təhdid yaradacaq "izlərin" ortaya çıxmasına səbəb olur. Müxtəlif şərt və səbəblərdən asılı olaraq, həmin informasiyaların qorunması zərurəti ortaya çıxır. Virtual sosial şəbəkələrdə məhz həmin həssaslıq tələb edən informasiyaların üzə çıxarılması, aşkarlanması, başqaları tərəfindən ələ keçirilməsi ehtimalı və qorxusundan doğan xeyli folklor faktları mövcuddur.

Nümunələrə diqqət yetirək:

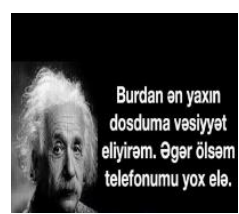

Azərbaycandilli virtaul mühitdə geniş populyarlıq qazanmış Albert Eynşteyn obrazı (rəsmi) fonunda təqdim olunan bu folklorik fakt - "Burdan an yaxın dosduma vasiyyat eliyirzm. Ogar ölsəm telefonumu yox elə”, əslində sosial şəbəkələrdə geniş yayılmış və variantlaşmış kollektiv rəyin təqdimat formalarından biridir. Virtual sosial şəbəkə istifadəçilərinin hər birinin yaşadığı emosiyanın folklorik modeldə ifası kimi ortaya çıxan bu fakt fərdi məlumatlara həssaslıqdan doğan, daha doğrusu, milli mentalitet vo stereotiplərin təzyiqi altında meydana çıxan narahatığın ifasıdır. Təbii ki, komik və ironik üslubun da semantik baxımdan mühüm rolu vardır.

Yaxud başqa bir nümunədə təsvir olunur ki, "Kişi xəstələnir və deyir: arvad təcili yardım çağır, ölürəm. Arvad deyir ki, telefonun kodunu de zəng edim. Kişi baxır ki, vəziyyət pisdir dərhal deyir: ehtiyac yoxdur, ölüm haqdır”. Deməli, fərdi məlumatlara olan həssaslıq yaradıcılıqda ölümlə müqayisə edilmək potensialındadır.

Digər bir nümunədə isə ər və arvad münasibətləri fərdi məlumatların təhlükəsizliyi kontekstində diqqət mərkəzinə gətirilir:

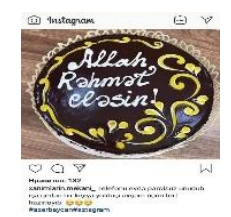

İnstagram sosial şəbəkəsində "xanimlarin.mekani” hesabından yayılan bu faktda - "telefonu evdə parolsuz unudub işə gedən bir kişiyə yoldaşı axşam üçün tort hazırlayıb - Allah rəhmət eləsin!” yenə də rəqəmsal ünsiyyət vasitəsində toplananan informasiyaların - fərdi məlumatların yaratdı̆̆ konflikt, dramatik situasiya təsvir olunur.

Watsapp-da geniş populyarlıq qazanmış aşağıdakı nümunə isə fərdi məlumata həssaslığın ən yüksək mübaliğə şəklində ifasıdır ki, düşüncənin metaforikliyi baxımından xüsusilə diqqəti cəlb edir.

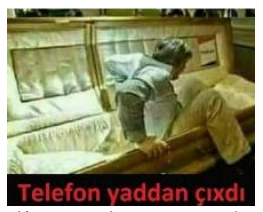

Fərdi məlumata həssaslıqdan doğan münasibətin ən dramatik şəkildə ifası kimi özünü göstərən bu nümunədə telefonu yaddan çıxan kişinin tabutdan belə durub geri qayitmağa cəhd etdiyi təsvir olunur.

Beləliklə, komik effekt yaradan, gülüş doğuran bu kimi folklorik faktlar, əslində, fərdi məlumat və şəxsi həyatla bağlı həssaslı̆̆ın dorəcəsini göstərir. Çünki milli mentalitet və sosial stereotiplərindən qaynaqlanan ictimai qınaq və sosial nəzarət fordi daim basq1 və təzyiq altında saxlamaqla psixoloji gərginlik yaradır. Belə bir stressiv vəziyyət, psixoloji gərginlik, yaradıcılıqda əks effektlə - gülüş, zarafat vasitəsilə təcəssüm olunma imkanı qazanır. Çünki gülüş, əslində ən kəskin ziddiyyət və gərginliyin, narahatlıq və həssaslı̆̆ı psixoloji boşalma ilə təcəssüm olunan təzahürdür.

Eyni zamanda təhlil etdiyimiz faktlar onu deməyə əsas verir ki, ənənəvi mədəni mühitdə norma yaradıcı institusional subyektlər (ata, baba, ağsaqqal, ağbirçək və nənələr), adət və ənənələrlə dəstəklənən, daha doğrusu, təbliğ olunan stereotiplər virtual kommunikativ mühitdə daha çox ironik və komik planda diqqət mərkəzinə gətirilir. Yuxarıda təhlil etdiyimiz hər bir folklorik fakt, əslində, milli mentalitet və stereotiplərin təzyiqi altında müəyyən çərçivə və qaydalara, norma və prinsiplərə tabe etdirilən insanın kollektiv emosional reaksiya kontekstində protestidir.

Beləliklə, İnternet mühitinin əsas istifadəçiləri və üzvləri yeniyetmə və gənclərdən təşkil olunduğu üçün, ideoloji olaraq ənənəvi folklorda fərdi məlumatlara həssaslıqdan dolayı meydana gələn faktlara münasibət fərqlidir. $\mathrm{Bu}$ mühitin iştirakçıları və yaradıcıları alternativ baxışın daşıyıcısı olduğu üçün milli mentalitet və stereotiplərin təsiri ilə fərdi məlumatlara olan həssaslıq daha çox ironik və komik planda özünü büruzə etdirir. Onənəvi folklor mühitində yaşlıların (yaşlılığın) ideoloji və institusional təbliğat alətləri kimi çıxış edən folklor nümunələrində milli mentalitet və stereotiplər təbliğ olunduğu halda, İnternet mühitində gənclərin baxış bucağından - kollektiv emosional reaksiyasından doğan virtual folklor faktlarında stereotiplər inkar olunur. $\mathrm{Bu}$ proses şəxsi həyat və fərdi məlumatların təhlükəsizliyinə həssaslığa təhrik edən milli mentalitet və stereotiplərə münaibətdə özünü göstərir. 


\section{“Informasiya tohlükosizliyinin aktual multidissiplinar elmi-praktiki problemlori” V respublika konfransı, 29 noyabr 2019-cu il}

\section{İSTINADLAR}

[1] Oliquliyev R.M., Mahmudov R.Ș. Milli mentalitet kontekstində fərdi məlumatların həssaslı̆̆ı və onların təhlükəsizliyinin təmin olunmasi məsələləri. İnformasiya cəmiyyəti problemləri, 2019, №2, 117-128.

[2] Haqverdiyev V. Atalar sözlərinə informatik yanaşma. Azərbaycan qəzeti, 1 mart 2009, s. 10

[3] İmançer, D. "Sosyal psikolojik açidan stereotip kavraminin dil ve metin analizinde kullanimi". Selçuk İletişim 3 (2013), s. 128-142;

[4] İmançer, D. "Stereotipleri anlamak". Ege Üniversitesi İletișim Fakültesi Yeni Düşünceler Hakemli E-Dergisi (2008), s. 301-320;

[5] "Kitabi-Dədə Qorqud". Әsli və sadələșdirilmiş mətnlər. Bakı: Öndər nəşriyyat, 2004, $376 \mathrm{~s}$

[6] Qarayev S. Folklor vasitəsi ila qrup və yaxud milli psixologiyanın öyrənilməsi. "Dədə Qorqud" elmi-ədəbi toplu. Bak1: "Elm və təhsil", 2018/2, s. 72-79,

[7] Quliyev Q. Dəlidən doğru xəbər. Bakı: Mütərcim, 1999, $160 \mathrm{~s}$.

[8] Limon, S, Oral Kara, N, Antalyalı, Ö. Yönetim literatüründe stereotip (kalipyargi) kavrami: ulusal ve uluslararasi alandakı yönetim araştırmaları üzerine bir inceleme. Süleyman Demirel Üniversitesi Vizyoner Dergisi, (2019). 10 (23), s. 195-211.

[9] Orucov Ә. Azərbaycan dilinin izahlı lüğəti. Dörd cilddə. IV cild, Bakı: Şərq-Qərb, 2006, $712 \mathrm{~s}$.

[10] "Taqq1lbab" və Zəncirbab" Ordubad qapılarının bəzəyidir. "El həyatı" qəzetinin 26 may 2019-cu il sayı. https://nuhcixan.az/news/cemiyyet/15791-taqqilbab-ve-zencirbabordubad-qapilarinin-bezeyidir

[11] Vəliyev F. Xalq yaşayış məskənləri // Azərbaycan etnoqrafiyası. Üç cilddə, II cild, Bak1: Şərq-Qərb, 2007, 384 s., s. 15-39.

[12] Yaqubqızı M. Atalar sözləri (Tərt. ed: Yaqubqızı M.). Bakı: 2013, 476 s.

\section{THE FOLKLORIC APPEARANCE OF SENSITIVITY TO PERSONAL INFORMATION IN THE CONTEXT OF NATIONAL MENTALITY AND STEREOTYPES}

Hikmat Guliyev

ANAS Institute of Folklore, Baku, Azerbaijan quliyevh@mail.ru

Abstract - The security of the personal information is one of the most urgent problems of modern times. Ensuring the security of the personal information in the present conditions, where the internet has become the main means of communication, is the problem connected not only with the technological, but also with the international law and national mentality. In the article the concept of the personal information is studied in the context of folklore, the folkloric manifestations formed and experienced by the influence of the national mentality and stereotypes are analyzed. Along with the traditional folklore examples, the facts noted from the virtual social networks are also involved in the investigation. As a result of the research, it is mentioned that sensitivity to the personal information caused by the national mentality and stereotypes in the socio-cultural environment of Azerbaijan has become more subject of irony in the virtual environment where the social control and pressure are reduced. And it causes the formation of the peculiar folklore manifestations in the virtual environment.

Key words - the national mentality, stereotypes, the personal information, the information security, Internet folklore, the traditional folklore 